\title{
Organic Nitrogen of Atmospheric Aerosols in the Coastal Area of Seto Inland Sea
}

\author{
Tokuhiro Nakamura ${ }^{1,2 *}$, Yasushi Narita ${ }^{3}$, Keizo Kanazawa², Mitsuo Uematsu ${ }^{3,4}$ \\ ${ }^{1}$ Department of Liberal Arts, College of Bioresource Sciences, Nihon University, Fujisawa-shi, Kanagawa 252-0880, Japan \\ ${ }^{2}$ Department of General Education, National Institute of Technology, Kagawa College, Mitoyo-shi, Kagawa 769-1192, \\ Japan \\ ${ }^{3}$ International Advanced Research, Center for International Collaboration, Atmosphere and Ocean Research Institute, \\ The University of Tokyo, Kashiwa-shi, Chiba 277-8564, Japan \\ ${ }^{4}$ Center for Environmental Science in Saitama, Kazo-shi, Saitama 347-0115, Japan
}

\begin{abstract}
Chemical compositions and particle number densities of atmospheric aerosols were measured in the coastal area of Seto Inland Sea during the spring of 2015. The mean concentrations of $\mathrm{NH}_{4}^{+}, \mathrm{NO}_{3}{ }^{-}$, and water-soluble organic nitrogen $\left(\mathrm{ON}_{\mathrm{ws}}\right)$ in the total (fine and coarse) particles were 1.6, 0.85 , and $0.28 \mu \mathrm{g} \mathrm{N} \mathrm{m}{ }^{-3}$, respectively. Although $\mathrm{NO}_{3}{ }^{-}$existed in fine and coarse particles, while $\mathrm{NH}_{4}^{+}$and $\mathrm{ON}_{\mathrm{ws}}$ existed primarily in fine particles. The contribution of $\mathrm{ON}_{\mathrm{ws}}$ to the total nitrogen was approximately $10 \%$, however, these fractions are comparable to the contribution of fine $\mathrm{NO}_{3}{ }^{-}$and coarse $\mathrm{NH}_{4}{ }^{+}$.

The dry deposition fluxes of particulate $\mathrm{NH}_{4}, \mathrm{NO}_{3}{ }^{-}$, and $\mathrm{ON}_{\mathrm{ws}}$ were 280,660 and $83 \mu \mathrm{g} \mathrm{N} \mathrm{m}{ }^{-2}$ day ${ }^{-1}$, respectively. The dry deposition flux of $\mathrm{NO}_{3}{ }^{-}$was more effective than any other nitrogen compounds, since the deposition rate depends upon the size distribution. The dry deposition flux of $\mathrm{ON}_{\mathrm{ws}}$ was approximately $8.1 \%$ of nitrogen compounds, however, it is found that $\mathrm{ON}_{\mathrm{ws}}$ should be considered in evaluating the effects of nitrogen compounds on marine ecosystems.
\end{abstract}

Keywords: Nitrogen compounds; Atmospheric pollutants; Atmospheric deposition of nutrients.

\section{INTRODUCTION}

The Seto Inland Sea is recognized as a beautiful scenic area not only in Japan, but also globally, and it is a treasure trove of valuable fishery resources (Ishii and Yanagi, 2006). It is also one of the most industrialized regions in Japan and characterized by frequent occurrence of red tides, therefore, to prevent this problem, chemical oxygen demand (COD) and total amount of nitrogen and phosphorus have been regulated (Hori et al., 2008). As a result, the water quality has continued to improve, the occurrence of red tides has decreased, and the transparency of the seawater has been restored (Tada et al., 2010). However, recently, concerns impacting the fishery industry have been identified, such as the discoloration of laver aquaculture (Tada et al., 2010) and

This article is an English version of "Organic Nitrogen of Atmospheric Aerosols in the Coastal Area of Seto Inland Sea [Japanese]" published in the Earozoru Kenkyu in Mar. 2017.

* Corresponding author.

Tel.: +81-466-84-3721; Fax: +81-466-84-3721

E-mail address: nakamura.tokuhiro@nihon-u.ac.jp the reduction in fish caught due to the decrease of nutrients in the seawater (Tanda et al., 2014).

The inflow of atmospheric pollutants such as yellow dust and anthropogenic substances from the East Asian has been actualized (Zhou et al., 1990; Uematsu et al., 1992), and the coastal area of the Seto Inland Sea is also affected by these pollutants (Nakamura et al., 2015). Based on a simulation using the chemical transport model, approximately $48 \%$ of the anthropogenic nitrogen compounds transported from China are deposited in the Yellow Sea, the East China Sea, and the Sea of Japan, and the importance of sea salt particles in this deposition process has been indicated (Itahashi et al., 2016). Moreover, these deposits affect marine biological production (Uemastu et al., 2004). Therefore, it is necessary to obtain information on the nitrogen compounds deposited in the ocean from the atmosphere. Previous Studies have indicated that the inflow pathways of nutrients to the Seto Inland Sea are primarily from the open ocean (Pacific) (Ishii and Yanagi, 2006), bottom sediment, and rivers (Tada et al., 2010), but little is understood about the inflow from the atmosphere (Nakamura et al., 2015).

Among the nitrogen compounds present in the atmospheric aerosols, inorganic nitrogen has been generally measured. Although research on organic nitrogen has been increasing in recent years, despite its importance, it has been studied significantly less than inorganic nitrogen (Cornell et al., 
1995). Currently, there is limited information regarding the concentration of organic nitrogen, its ratio to total nitrogen, sources, size distribution, behavior in the atmosphere, and deposition; in addition, these findings vary greatly depending on the individual studies (Jickells et al., 2013).

After the deposition of organic nitrogen in the ecosystems, some forms can be used as nutrients directly (Murphy et al., 2000) or after decomposition (Smidt, 1994) by microorganisms. However, some forms are toxic to organisms (Paumen et al., 2009). As mentioned above, organic nitrogen has various chemical forms, however, it needs to be considered to prevent the underestimation of the deposition of nitrogen compounds (Jickells et al., 2013). To date, there have been no studies on organic nitrogen in atmospheric aerosols in the coastal area of the Seto Inland Sea.

In this study, we focused on the nitrogen compounds in aerosols that are utilized as nutrients in the ecosystems. The purpose of this study was to determine the chemical forms of the nitrogen compounds (organic and inorganic) based on their particle size, importance and sources of organic nitrogen, and the deposition of nutrients by atmospheric aerosols in the coastal area of the Seto Inland Sea.

\section{METHODS}

Atmospheric aerosols were measured on a rooftop (approximately $15 \mathrm{~m}$ above the ground) at the National Institute of Technology, Kagawa College (Mitoyo City, Kagawa Prefecture), between February 15 and March 20, 2015 (Fig. 1).

An automated sequential air sampler (Tokyo Dylec Co., Ltd., GS-10) was used to collect the atmospheric aerosols on pre-combusted $\left(4 \mathrm{~h}\right.$ at $\left.450^{\circ} \mathrm{C}\right)$ quartz fiber filters (Pallflex Products Co., Model 2500QAT-UP). The samples were collected at $24 \mathrm{~h}$ intervals at a flow rate of $20 \mathrm{~L} \mathrm{~min}^{-1}$. The inline 2-stage filter folders (Nilu, NL-I-02) equipped with a multi-nozzle cascade impactor (Tokyo Dylec Co., Ltd., NL2.5A) were used to separate the atmospheric aerosols

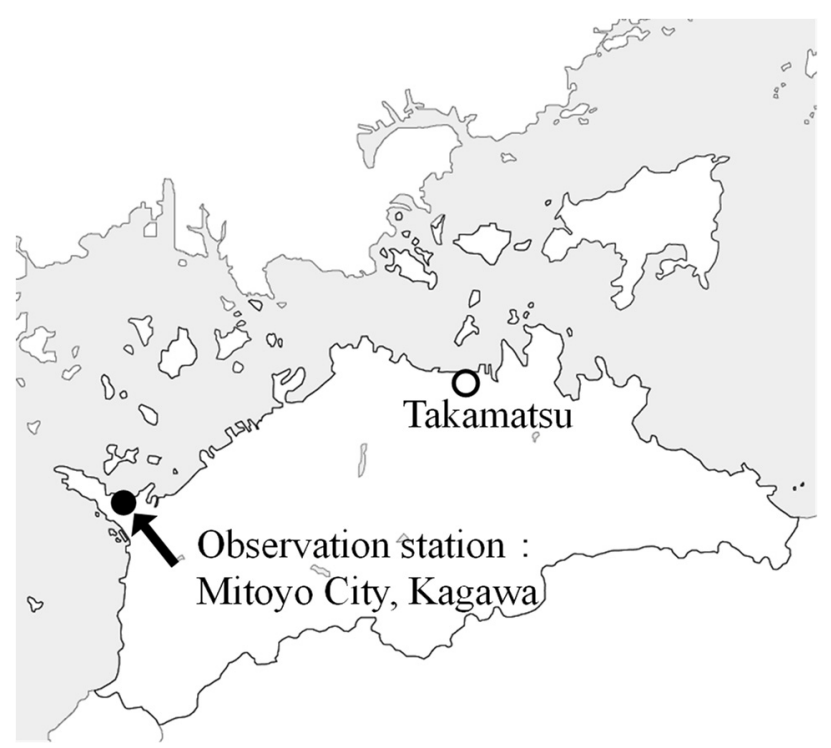

Fig. 1. Observation station (Kagawa prefecture). according to their aerodynamic diameters, which were segregated into fine $(<2.5 \mu \mathrm{m})$ and coarse $(>2.5 \mu \mathrm{m})$ particles. The air sampler can hold a maximum of 10 filter holders, and the samples can be automatically changed every $24 \mathrm{~h}$. In this study, the period of sample attachment to the air sampler, including the sampling time, was set to 4 days to prevent deterioration of the samples. The filters were stored at approximately $-20^{\circ} \mathrm{C}$ until the analysis.

The atmospheric aerosols collected on the filters were extracted by shaking with $50 \mathrm{~mL}$ ultra-pure water (specific resistivity: approximately $18 \mathrm{M}$ in a polyethylene container for $30 \mathrm{~min}$. The water-extracted aerosol samples were filtered through a glass fiber filter (Whatman $\mathrm{GF} / \mathrm{F}$ ). The filtrates were analyzed for $\mathrm{Na}^{+}, \mathrm{NH}_{4}^{+}, \mathrm{K}^{+}, \mathrm{Mg}^{2+}, \mathrm{Ca}^{2+}, \mathrm{Cl}^{-}$, $\mathrm{NO}_{3}{ }^{-}$, and $\mathrm{SO}_{4}{ }^{2-}$ with ion chromatography (DIONEX, DX$320)$, and the water-soluble total nitrogen $\left(\mathrm{TN}_{\mathrm{ws}}\right)$. The $\mathrm{TN}_{\mathrm{ws}}$ was analyzed using high-temperature catalytic oxidation at a furnace temperature of $720^{\circ} \mathrm{C}$ (Shimadzu Co., TNM-1) with a chemiluminescence gas analyzer (Shimadzu Co., TNM-1).

The blank for each component was determined using six blank filters, and the mean value was subtracted from the values obtained for actual samples. The detection limits of each component were determined to be three times the standard deviation of the measured values of the six blank filters. For the fine particles $(<2.5 \mu \mathrm{m})$, the blank values for $\mathrm{NH}_{4}^{+}, \mathrm{K}^{+}, \mathrm{Cl}^{-}, \mathrm{NO}_{3}^{-}$, and $\mathrm{SO}_{4}{ }^{2-}$ were $0.038,0.018,0.025$, 0.044 , and $0.037 \mathrm{mg} \mathrm{L}^{-1}$, respectively, and the other components were within $0.010 \mathrm{mg} \mathrm{L}^{-1}$. The detection limits were $0.014 \mathrm{mg} \mathrm{L}^{-1}$ for $\mathrm{NH}_{4}{ }^{+}$and within $0.010 \mathrm{mg} \mathrm{L}^{-1}$ for the other components. For the coarse particles $(>2.5 \mu \mathrm{m})$, the blank values for $\mathrm{NH}_{4}{ }^{+}, \mathrm{K}^{+}, \mathrm{Cl}^{-}, \mathrm{NO}_{3}^{-}$, and $\mathrm{SO}_{4}{ }^{2-}$ were 0.019 , $0.016,0.024,0.042$, and $0.032 \mathrm{mg} \mathrm{L}^{-1}$, respectively, and the other components were within $0.010 \mathrm{mg} \mathrm{L}^{-1}$. The detection limits were within $0.010 \mathrm{mg} \mathrm{L}^{-1}$ for all ion components. The blank values for $\mathrm{TN}_{\mathrm{ws}}$ were 0.037 and $0.026 \mathrm{mg} \mathrm{L}^{-1}$, whereas the detection limits were 0.013 and $0.016 \mathrm{mg} \mathrm{L}^{-1}$, for fine and coarse particles, respectively.

The concentrations of non-sea-salt sulfate (nss- $\mathrm{SO}_{4}{ }^{2-}$ ) and nss-calcium (nss- $\mathrm{Ca}^{2+}$ ) were calculated from the weight ratios of $\mathrm{SO}_{4}{ }^{2-} / \mathrm{Na}^{+}(0.251)$ and $\mathrm{Ca}^{2+} / \mathrm{Na}^{+}(0.038)$ in the seawater.

The concentration of water-soluble organic nitrogen $\left(\mathrm{ON}_{\mathrm{ws}}\right)$ in the atmospheric aerosols was obtained by subtracting the water-soluble inorganic nitrogen $\mathrm{IN}_{\mathrm{ws}}\left(\mathrm{NO}_{3}{ }^{-} \mathrm{N}+\mathrm{NH}_{4}{ }^{+}-\mathrm{N}\right)$ from $\mathrm{TN}_{\mathrm{ws}}\left(\mathrm{ON}_{\mathrm{ws}}=\mathrm{TN}_{\mathrm{ws}}-\mathrm{IN}_{\mathrm{ws}}\right)$. In this study, negative values of $\mathrm{ON}_{\mathrm{ws}}$ were set to zero. However, when calculating the concentrations of $\mathrm{ON}_{\mathrm{ws}}$, the measurement errors of $\mathrm{IN}_{\mathrm{ws}}$ and $\mathrm{TN}_{\mathrm{ws}}$ were propagated, and the errors were significant when the concentrations of $\mathrm{IN}_{\mathrm{ws}}$ were high and those of $\mathrm{ON}_{\mathrm{ws}}$ were low (Cornell et al., 2003). When $\mathrm{ON}_{\mathrm{ws}}$ was 50\% of $\mathrm{TN}_{\mathrm{ws}}$, the coefficient of variation was approximately $10 \%$, whereas, when $\mathrm{ON}_{\mathrm{ws}}$ was $10 \%$ of $\mathrm{TN}_{\mathrm{ws}}$, the coefficient of variation was approximately $80 \%$ (Hansell, 1993; Cornell et al., 2003). Additionally, when measuring $\mathrm{TN}_{\mathrm{ws}}, \mathrm{ON}_{\mathrm{ws}}$ potentially was not completely oxidized to $\mathrm{NO}_{\mathrm{x}}$ (Scudlark et al., 1998), and $\mathrm{ON}_{\mathrm{ws}}$ volatilized during the aerosol sampling (Matsumoto and Yamato, 2016). Given that the $\mathrm{ON}_{\mathrm{ws}}$ values in this study were partly negative, it is assumed that the $\mathrm{ON}_{\mathrm{ws}}$ values may have been underestimated. 
Simultaneously, the mass concentration of the atmospheric aerosols with aerodynamic diameters smaller than $2.5 \mu \mathrm{m}$ $\left(\mathrm{PM}_{2.5}\right)$ (Thermo, FH62C14) was measured at 30 min intervals, and the particle number density was measured using an optical particle counter (Rion Co., Ltd., KC01D) in five size fractions of $>0.3,>0.5,>1,>2$, and $>5 \mu \mathrm{m}$ at $15 \mathrm{~min}$ intervals.

A backward trajectory analysis was conducted to estimate the air mass history that reached the observation station using the NOAA HYSPLIT4 model (Draxler and Rolph, 2016) with a tracking time of $72 \mathrm{~h}$ at an altitude of $500 \mathrm{~m}$. The meteorological field was also estimated using weather maps provided by Japan Metrological Agency.

\section{RESULTS AND DISCUSSION}

\section{Overviews of the Observation Results}

The variations in the particle number densities $(>0.3$, $>2 \mu \mathrm{m})$ are shown in Fig. 2. These particle sizes indicate the distinction between the fine and coarse classifications. The variations of nss- $\mathrm{SO}_{4}{ }^{2-}$ and nss- $\mathrm{Ca}^{2+}$ in the aerosols are shown in Fig. 3. Periods A-F are treated as highconcentration events, which demonstrated continuous rapid increases. In particular, the daily averages of $\mathrm{PM}_{2.5}$ were $27-35 \mu \mathrm{g} \mathrm{m}^{-3}$ in Period B (2/23-2/26) and 28-34 $\mu \mathrm{g} \mathrm{m}^{-3}$ in Period F (3/16-3/18), near the environmental standard value of $35 \mu \mathrm{g} \mathrm{m}^{-3}$. On February 23 and 24 (Period B), the Japan Meteorological Agency reported the observation of a Kosa (aeolian dust) event in Takamatsu (http://www.data.jma.go. jp/gmd/env/kosahp/kosa table_2015.html; accessed 17 April 2016). In this study, a rapid increase in the $>2 \mu \mathrm{m}$ particle number densities and the concentration of nss- $\mathrm{Ca}^{2+}$, which is an indicator of mineral particles, were also observed (Fig. 3).

The representative weather charts are shown in Fig. 4 to estimate the causes of the increase in pollutants for each period. In Periods A, B, C, and E, high concentrations of pollutants were observed due to their transport to the observation station by high-pressure systems near the continent with the development and passage of cold fronts. In Period D, the atmospheric pollutants were transported by

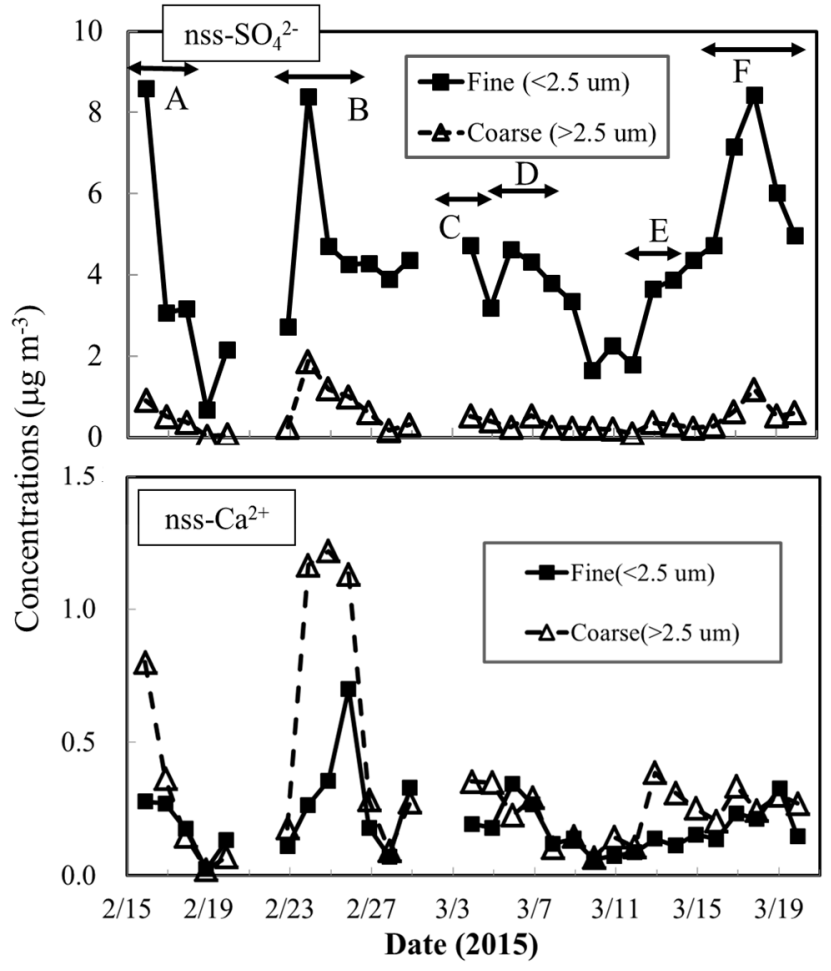

Fig. 3. Variations in particulate nss- $\mathrm{SO}_{4}{ }^{2-}$ and nss- $\mathrm{Ca}^{2+}$.

a migratory high-pressure system, and in Period F, the observation area was covered with a high-pressure system, rising temperatures, and minimal air mass movement. The Period F atmospheric conditions were thought to have been primarily affected by the industrial area of the Seto Inland Sea and were supported by 72-hour backward trajectories (Fig. 5).

\section{Nitrogen Components in Atmospheric Aerosols}

The variations of water-soluble inorganic nitrogen $\left(\mathrm{NH}_{4}{ }^{+}\right.$, $\left.\mathrm{NO}_{3}{ }^{-}\right)$and water-soluble organic nitrogen $\left(\mathrm{ON}_{\mathrm{ws}}\right)$ are shown in Fig. 6. The aerosol samples corresponding to the highconcentration events in Periods A-F (shown in Fig. 2) were

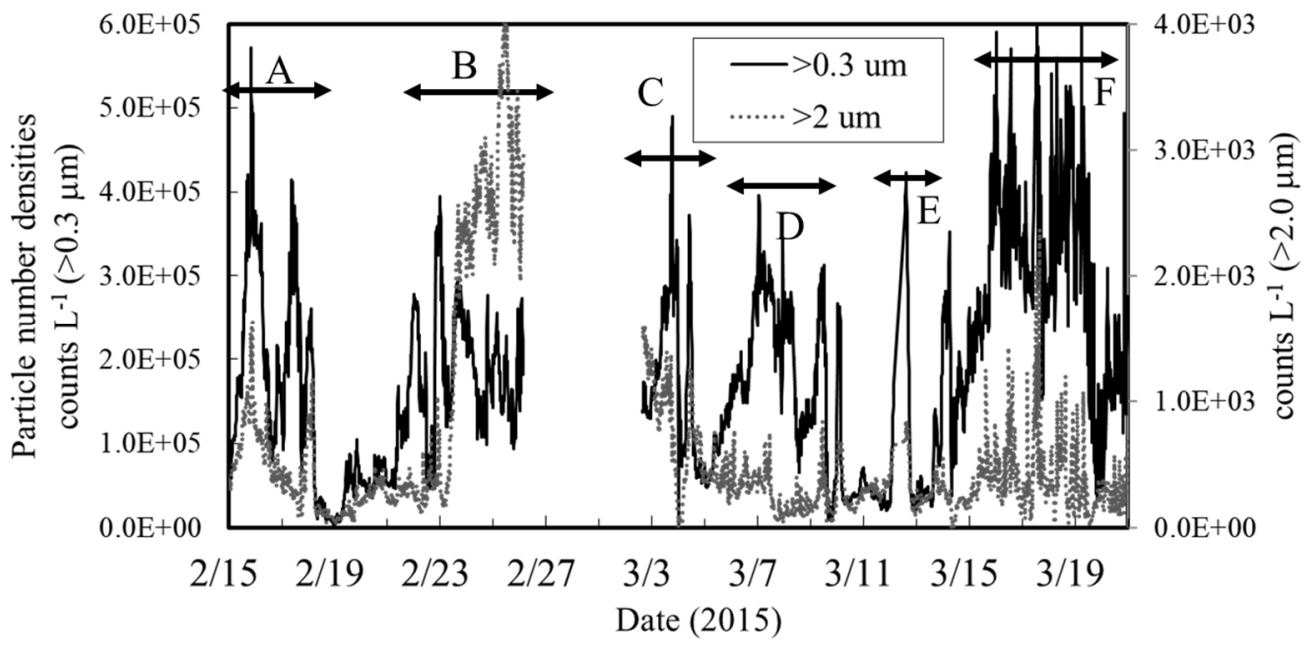

Fig. 2. Variations in particle number densities $(>0.3,>2 \mu \mathrm{m})$. 

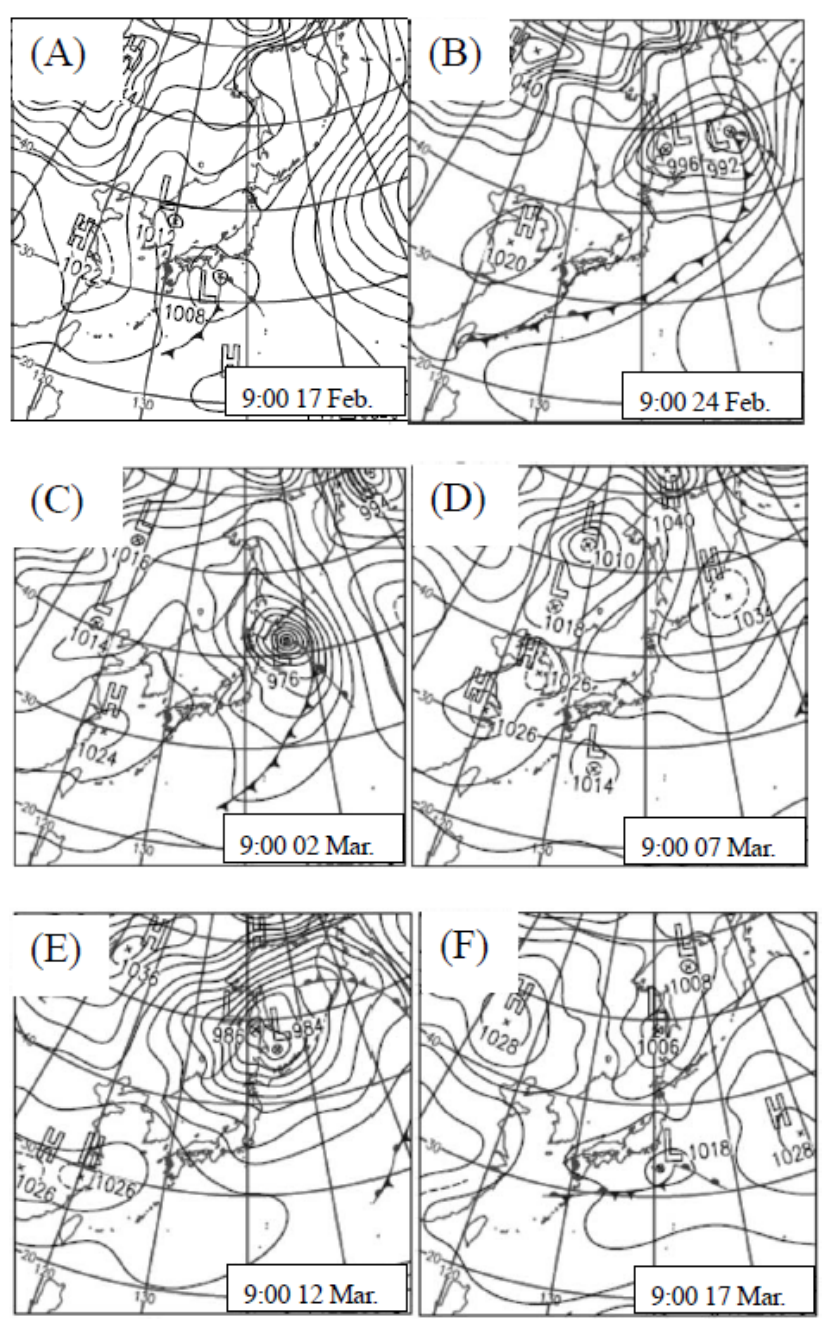

Fig. 4. Weather charts at 0900 JST on (A) February 17, (B) 24. (C) March 2, (D) 7, (E) 12 and (F) 17, 2015 provided by Japan Metrological Agency (http://www.data.jma.go.jp/ fcd/yoko/hibiten; accessed 17 Arp. 2016). defined as polluted atmospheric conditions, and all the other samples were defined as normal atmospheric conditions. The mean concentrations and the ratios of each nitrogen component classified by particle size and categorized into normal or polluted atmospheric conditions are shown in Fig. 7.

\section{Inorganic Nitrogen Components}

The variation of $\mathrm{NH}_{4}{ }^{+}$in the fine particles (Fig. 6) was similar to that of the nss- $\mathrm{SO}_{4}{ }^{2-}$ in the fine particles (Fig. 3), and the $>0.3 \mu \mathrm{m}$ particle number density (Fig. 2). The mean concentrations and standard deviations of the total (fine and coarse) $\mathrm{NH}_{4}{ }^{+}$in the normal and polluted conditions were 1.0 \pm 0.46 and $2.1 \pm 0.80 \mu \mathrm{g} \mathrm{N} \mathrm{m}^{-3}$, respectively, indicating that the concentration level was approximately 2.1 times higher in the polluted conditions than in the normal conditions. The proportions of fine particles in the normal and polluted conditions were $97 \%$ and $92 \%$, respectively. Although the proportion of fine particles decreased slightly during the dust event, the size distribution did not change significantly.

The variation of $\mathrm{NO}_{3}{ }^{-}$in Periods $\mathrm{A}$ and $\mathrm{B}$ was similar to that of the $>2 \mu \mathrm{m}$ particle number density (Fig. 2) and the coarse nss-Ca ${ }^{2+}$ (Fig. 3). In Period F, that potentially had been affected by the industrial area of the Seto Inland Sea, $\mathrm{NO}_{3}{ }^{-}$ primarily existed as fine particles. As indicated here, the size distribution of $\mathrm{NO}_{3}{ }^{-}$shifted significantly by atmospheric conditions. The mean concentrations and standard deviations of $\mathrm{NO}_{3}{ }^{-}$in the normal and polluted conditions were $0.47 \pm$ 0.23 and $1.2 \pm 0.41 \mu \mathrm{g} \mathrm{N} \mathrm{m}^{-3}$, respectively; thus, the concentration level was approximately 2.6 times higher in the polluted conditions than in the normal conditions. Coarse particles have a high deposition velocity, which affects the amount of deposition. Therefore, the formation of coarse $\mathrm{NO}_{3}{ }^{-}$was investigated. The correlation between the nss-Ca ${ }^{2+}$ and $\mathrm{NO}_{3}{ }^{-}$coarse particles is very high $\left(R^{2}=0.94\right)$ (Fig. 8(a)) at equivalent concentrations (neq $\mathrm{m}^{-3}$ ); this implies that the formation of coarse $\mathrm{NO}_{3}{ }^{-}$is correlated with mss-Ca ${ }^{2+}$. Furthermore, the chlorine loss (Cl-loss) estimated from

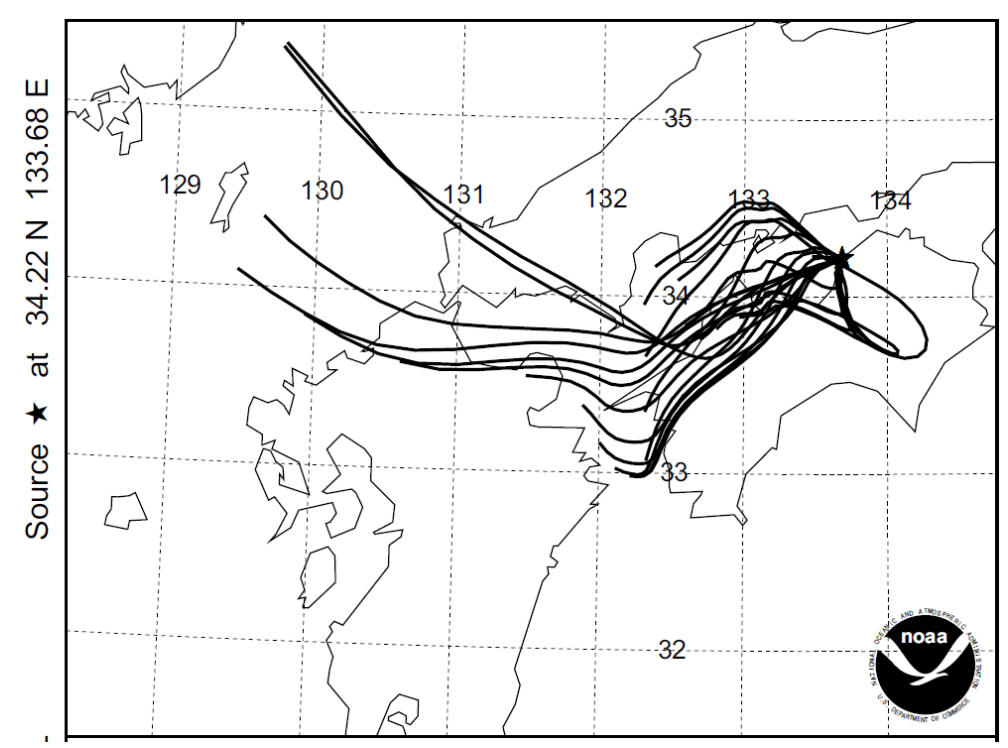

Fig. 5. 72 hours backward trajectories during the Period F at every 2 hours starting from 0900. JST on 15 March to 0900 on 17 March (NOAA ARL HYSPLITS4 Model). 


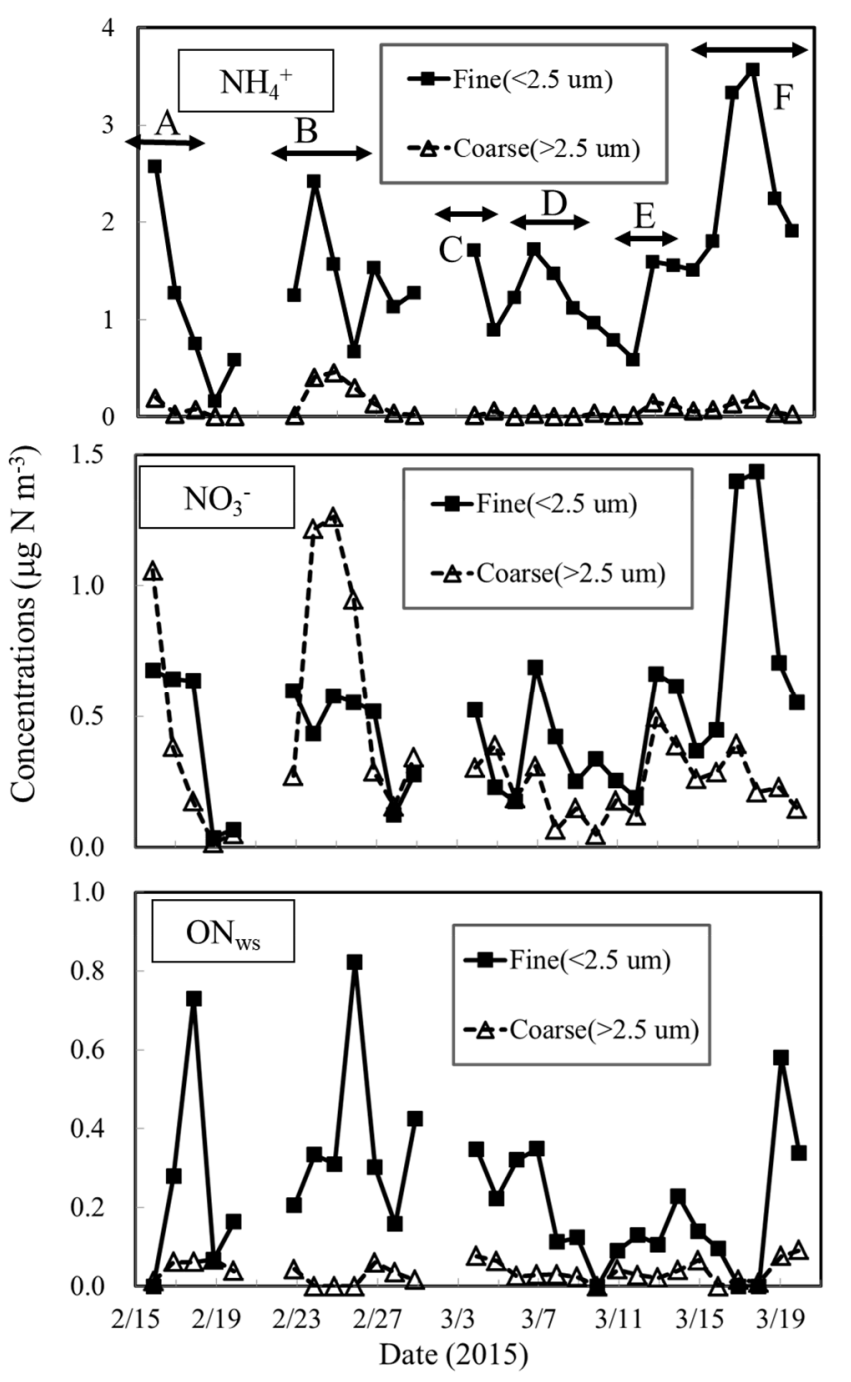

Fig. 6. Variations in particulate nitrogen compounds $\left(\mathrm{NH}_{4}^{+}\right.$, $\mathrm{NO}_{3}{ }^{-}$and $\mathrm{ON}_{\mathrm{ws}}$ ).

Eq. (1) from the $\mathrm{Cl}^{-}$concentration, with $\mathrm{Na}^{+}$entirely from sea salt. By adding this value to nss- $\mathrm{Ca}^{2+}$, the relationship between $\mathrm{NO}_{3}{ }^{-}$and nss-Ca ${ }^{2+}+\mathrm{Cl}$-loss is almost 1:1 (Fig. 8(b)). Here, the concentration unit is equivalent concentrations $\left(\right.$ neq $\left.\mathrm{m}^{-3}\right)$.

$$
\text { Cl-loss }=1.174 \times \mathrm{Na}^{+}-\mathrm{Cl}^{-}
$$

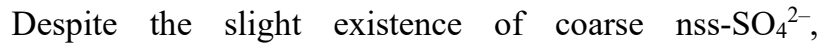
approximately $65 \%$ of $\mathrm{NO}_{3}{ }^{-}$is combined with nss-Ca ${ }^{2+}$ as evidenced by the slope value of 0.65 in Fig. 8(a). Based on the relationship between $\mathrm{NO}_{3}{ }^{-}(x)$ and Cl-loss $(y)(y=0.28 x$ +3.8 , coefficient of determination $R^{2}=0.64$ ), it is estimated that approximately $28 \%$ of $\mathrm{NO}_{3}{ }^{-}$has combined with sea salt. It can be assumed that the remaining $7.0 \%$ of $\mathrm{NO}_{3}{ }^{-}$has combined with other cations except nss- $\mathrm{Ca}^{2+}$ and $\mathrm{Na}^{+}$. This assumption also can be supported by the slope value of 0.93 in Fig. 8(b). Based on these findings, coarse $\mathrm{NO}_{3}{ }^{-}$has a relationship with mineral and sea salt particles, affecting the deposition rate of $\mathrm{NO}_{3}{ }^{-}$.

\section{Water-soluble Organic Nitrogen}

The mean concentrations of the total water-soluble organic nitrogen $\left(\mathrm{ON}_{\mathrm{ws}}\right)$ were 0.24 and $0.31 \mu \mathrm{g} \mathrm{N} \mathrm{m}^{-3}$ in the normal and polluted conditions, respectively. The concentration level was approximately 1.3 times higher in the polluted conditions than in the normal conditions, indicating a small difference between normal and polluted conditions. During all observation periods, approximately $87 \%$ of $\mathrm{ON}_{\mathrm{ws}}$ existed as fine particles, and the size distribution was similar to that of $\mathrm{NH}_{4}^{+}$. However, although the size distribution of $\mathrm{NH}_{4}^{+}$ did not shift during the dust event (Period B), it has been reported that $\mathrm{ON}_{\mathrm{ws}}$ related to mineral particles increased during a dust event in the eastern Mediterranean region (Mace et al., 2003). In the East China Sea in spring, the concentration of coarse $\mathrm{ON}_{\mathrm{ws}}$ increased during a dust event, which suggests that this increase is also related to mineral dust (Nakamura et al., 2006). On the other hand, in the Yellow Sea and Qingdao, the concentrations of both $\mathrm{IN}_{\mathrm{ws}}$ and $\mathrm{ON}_{\mathrm{ws}}$ increased during a dust event; the rate of increase for $\mathrm{IN}_{\mathrm{ws}}$ was the higher of the two, resulting in a decreased overall proportion of $\mathrm{ON}_{\mathrm{ws}}$ (Shi et al., 2010). In the coastal area of the Seto Inland Sea in this study, almost no coarse $\mathrm{ON}_{\mathrm{ws}}$ was detected in Period B during the dust event. This is because the source of the $\mathrm{ON}_{\mathrm{ws}}$ was not soil, and the concentration of $\mathrm{IN}_{\mathrm{ws}}$ had increased, especially with the notable increase in coarse $\mathrm{NO}_{3}{ }^{-}$during Period $\mathrm{B}$ (Fig. 6), affecting the calculated value of $\mathrm{ON}_{\mathrm{ws}}$. A portion of the $\mathrm{ON}_{\mathrm{ws}}$ could be lost during the long-distance transport between the observation station in this study and the significant pollutant sources, compared with that in the eastern Mediterranean region and the East China Sea.

The contribution of $\mathrm{ON}_{\mathrm{ws}}$ to the total nitrogen in the aerosol samples classified as the normal condition was $14 \%$ in both the fine and coarse particles, as shown in Fig. 7. These fractions are comparable to the contribution of fine $\mathrm{NO}_{3}{ }^{-}$and coarse $\mathrm{NH}_{4}{ }^{+}$. The $\mathrm{ON}_{\mathrm{ws}}$ contribution to total nitrogen in the aerosol samples, classified as polluted air, was $9.3 \%$ for the fine and $5.0 \%$ for the coarse particles. These results indicated that $\mathrm{ON}_{\mathrm{ws}}$ cannot be ignored as a nitrogen compound at this observation station.

Table 1 shows the comparison of the mean concentration of $\mathrm{ON}_{\mathrm{ws}}$ (total) and its contribution to total nitrogen in this study and other regions. The mean concentration of $\mathrm{ON}_{\mathrm{ws}}$ in the coastal region of the Seto Inland Sea was similar to that in an urban area, Kofu (Matsumoto et al., 2014), lower than in the coastal area strongly affected by continental pollutants (Shi et al., 2010), and higher than in the open ocean (Luo et al., 2016). The contribution of $\mathrm{ON}_{\mathrm{ws}}$ was high in the East China Sea and the South China Sea and was comparable to that in the other regions.

A correlation analysis between $\mathrm{ON}_{\mathrm{ws}}$ and the origins of combustion (nss- $\mathrm{SO}_{4}{ }^{2-}$ and $\mathrm{NO}_{3}{ }^{-}$), sea salt $\left(\mathrm{Na}^{+}\right)$, and soil $\left(\right.$ nss- $\mathrm{Ca}^{2+}$ ) was conducted for each particle size to determine the sources of the $\mathrm{ON}_{\mathrm{ws}}$ in the aerosols (Fig. 9). However, samples with $\mathrm{IN}_{\mathrm{ws}}$ concentrations higher than $\mathrm{TN}_{\mathrm{ws}}$ potentially contain measurement errors, so these were excluded from the graphed data. Significant correlations were seen with the fine particles, though not with the coarse particles. Because $\mathrm{ON}_{\mathrm{ws}}$ is not a single component, it is assumed that the size 
(a) Normal condition $(n=14)$

Fine

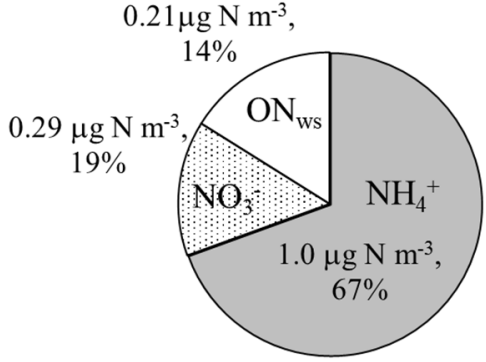

Total Nitrogen

$1.5 \mu \mathrm{g} \mathrm{N} \mathrm{m}^{-3}$

(b) Polluted condition $(n=15)$

Fine

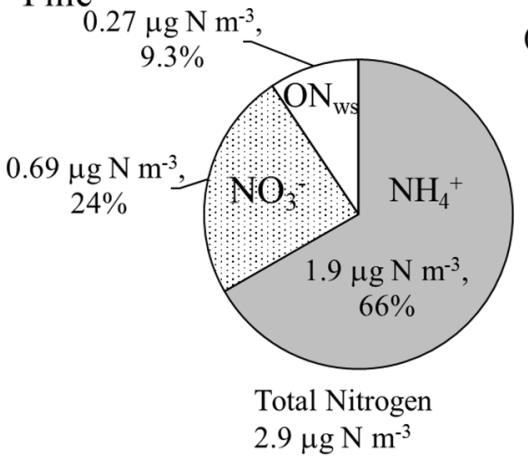

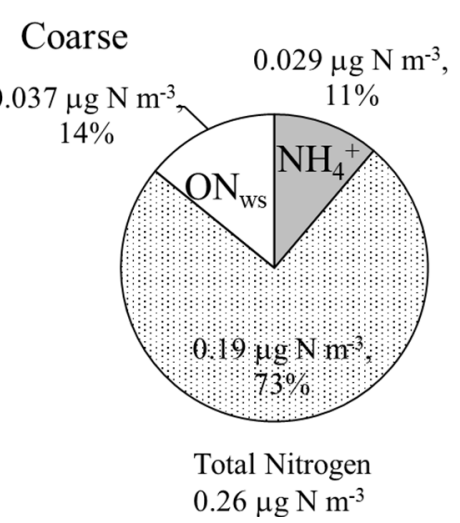

Coarse

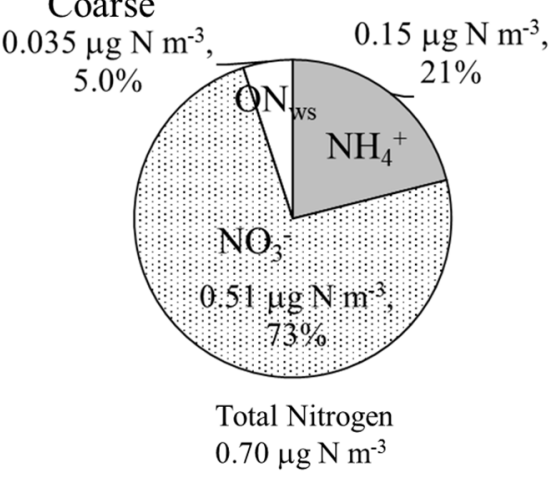

Fig. 7. Fractions of nitrogen compounds in (a) Normal and (b) Polluted conditions.
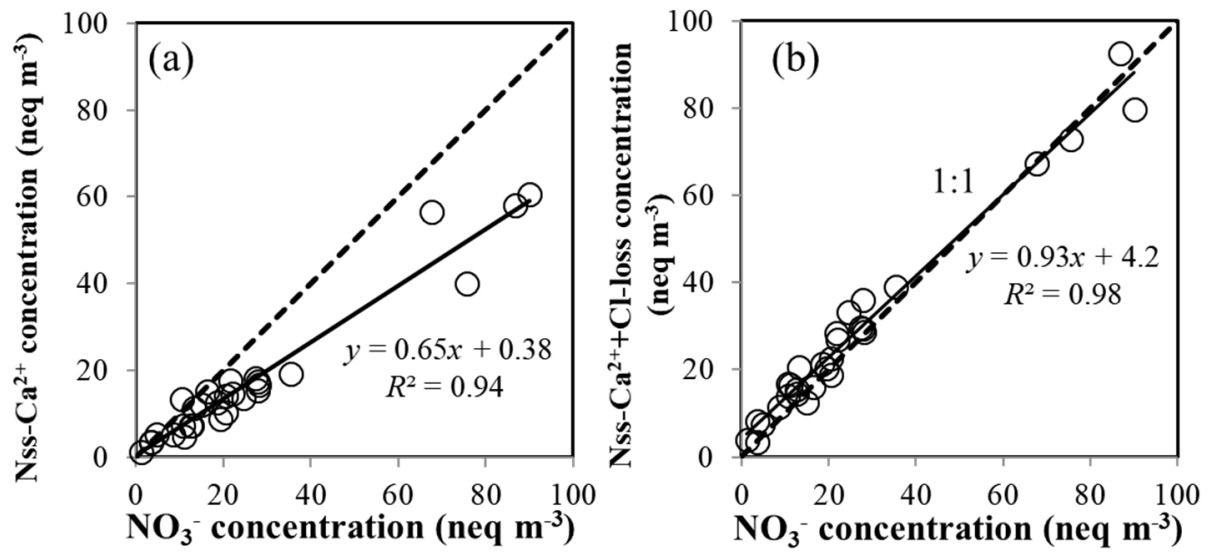

Fig. 8. Relationships between (a) $\mathrm{NO}_{3}{ }^{-}$and nss- $-\mathrm{Ca}^{2+}$, and (b) $\mathrm{NO}_{3}{ }^{-}$and nss-Ca ${ }^{2+}+\mathrm{Cl}-$ loss in the coarse particles (> $2.5 \mu \mathrm{m}$ ).

distribution and behavior differ depending on each component. However, based on the correlations between $\mathrm{ON}_{\mathrm{ws}}$ with nss$\mathrm{SO}_{4}{ }^{2-}$ and $\mathrm{NO}_{3}{ }^{-}$, combustion could be considered as a source of $\mathrm{ON}_{\mathrm{ws}}$ (Figs. 9(a) and 9(b)). Fine $\mathrm{ON}_{\mathrm{ws}}$ could be generated by combustion, the reactions between gaseous organic compounds and $\mathrm{NO}_{2}$, and secondary photochemical processes such as the photooxidation of gaseous organic nitrogen (Matsumoto et al., 2014). The increasing trend of the $\mathrm{ON}_{\mathrm{ws}}$ concentrations with higher pollutant concentrations is consistent with that reported in previous studies (Scudlark et al., 1998; Mace et al., 2003; Nakamura et al., 2006; Shi et al., 2010; Matsumoto et al., 2014; Luo et al., 2016;
Matsumoto and Yamato, 2016). The $\mathrm{ON}_{\mathrm{ws}}$ was not detected during Period F, which was thought to have been strongly affected by the local industries, and the concentration of nss- $\mathrm{SO}_{4}{ }^{2-}$ was high. The relationship between the $\mathrm{ON}_{\mathrm{ws}}$ and local atmospheric pollutants could not be identified because of the possibility of measurement errors due to high concentrations of $\mathrm{IN}_{\mathrm{ws}}$.

Interestingly, a significant correlation between nss-Ca ${ }^{2+}$ and $\mathrm{ON}_{\mathrm{ws}}$ in fine particles was observed (Fig. 9(d)), probably owing to the formation of secondary particles that are formed when gaseous organic nitrogen and other acidic substances react with mineral particles. However, because 
Table 1. Comparison of $\mathrm{ON}_{\mathrm{ws}}$ in total (fine and coarse) aerosols in different regions.

\begin{tabular}{|c|c|c|c|c|}
\hline Location & Date & $\begin{array}{l}\mathrm{ON}_{\mathrm{ws}} \\
\mu \mathrm{g} \mathrm{N} \mathrm{m}^{-3}\end{array}$ & $\begin{array}{l}\mathrm{ON}_{\mathrm{ws}} / \mathrm{TN} \\
\%\end{array}$ & References \\
\hline Seto Inland Sea (Normal) & Feb.-Mar. 2015 & 0.24 & 14 & This study \\
\hline Seto Inland Sea (Polluted) & Feb.-Mar. 2015 & 0.31 & 8.6 & This study \\
\hline Pacific Ocean and East China Sea (Autumn) & Sep.-Oct. 2002 & 0.76 & 24 & Nakamura et al., 2006* \\
\hline Pacific Ocean and East China Sea (Spring) & Mar. 2004 & 0.22 & 10 & Nakamura et al., 2006* \\
\hline Yellow Sea & Mar. 2005 & 2.9 & 17 & Shi et al., 2010* \\
\hline Yellow Sea & Apr. 2006 & 1.2 & 17 & Shi et al., 2010* \\
\hline Qingdao & Mar.-Apr. 2006 & 2.5 & 20 & Shi et al., 2010* \\
\hline South China Sea & Apr. 2005 & 0.91 & 34 & Shi et al., 2010* \\
\hline Urban site, Kofu & Aug. 2009-Jan. 2013 & 0.22 & 14 & Matsumoto et al., 2014* \\
\hline North Western Pacific Ocean (dust) & Mar.-Apr. 2014 & 0.16 & 5 & Luo et al., 2016* \\
\hline North Western Pacific Ocean (Background) & Mar.-Apr. 2014 & 0.15 & 14 & Luo et al., 2016* \\
\hline
\end{tabular}

* Calculated value from the origin data.

no correlation was seen with the coarse particles (Fig. 9(h)), the $\mathrm{ON}_{\mathrm{ws}}$ was not considered to be originated soil itself. These results suggest that some components of organic nitrogen in anthropogenic substances are adsorbed onto or react with mineral particles and exist stably in relatively aged air masses. Further research is necessary, including research on the $\mathrm{ON}_{\mathrm{ws}}$ relationship with coarse particles.

\section{Dry Deposition Flux of Nitrogen Compounds by Aerosols}

The dry deposition flux $(F)$ of particulate nitrogen compounds was calculated using Eq. (2) to estimate the effect of nitrogen components on the biota of the sea surface.

$F=V_{d} \cdot C_{a}$

Here, $V_{d}$ represents the deposition velocity $\left(\mathrm{cm} \mathrm{s}^{-1}\right)$, and $C_{a}$ represents the concentration of each nitrogen component in the atmosphere $\left(\mu \mathrm{g} \mathrm{N} \mathrm{m}^{-3}\right)$. The dry deposition velocity is a critical factor in estimating the deposition flux, but the velocity differs substantially due to the particle size distribution.

In this study, because the atmospheric aerosols were collected in two stages based on their size, we used $0.1 \mathrm{~cm} \mathrm{~s}^{-1}$ as the dry deposition velocity for fine particles and $2.0 \mathrm{~cm} \mathrm{~s}^{-1}$ for coarse particles (Duce et al., 1991; Nakamura et al., 2005, Uematsu et al., 2010), although the dry deposition velocity differed depending on weather conditions (such as wind speed, humidity, and air temperature). By calculating the deposition velocity based on the proportion of fine and coarse particles of each nitrogen component, we found the velocities for $\mathrm{NO}_{3}^{-}, \mathrm{NH}_{4}^{+}$, and $\mathrm{ON}_{\mathrm{ws}}$ to be $0.90,0.21$, and $0.34 \mathrm{~cm} \mathrm{~s}^{-1}$, respectively. Nakamura et al. (2005) and Kang et al. (2010) estimated the deposition fluxes using $1.7 \mathrm{~cm} \mathrm{~s}^{-1}$ for $\mathrm{NO}_{3}^{-}$and $0.22 \mathrm{~cm} \mathrm{~s}^{-1}$ for $\mathrm{NH}_{4}^{+}$as the deposition velocities in the East China Sea and the Sea of Japan. Chen et al. (2008) used $1.2 \mathrm{~cm} \mathrm{~s}^{-1}$ for $\mathrm{NO}_{3}{ }^{-}$and $0.1 \mathrm{~cm} \mathrm{~s}^{-1}$ for $\mathrm{NH}_{4}^{+}$as the velocities in the coastal area of northeastern Taiwan. Zhang et al. (2008) used $1.15 \mathrm{~cm} \mathrm{~s}^{-1}$ for $\mathrm{NO}_{3}{ }^{-}$and $0.6 \mathrm{~cm} \mathrm{~s}^{-1}$ for $\mathrm{NH}_{4}^{+}$as the velocities in the Yellow Sea and the East China Sea. Therefore, errors occur in the estimations of deposition flux due to the differences in the deposition velocities. In this study, the deposition velocity of $\mathrm{NO}_{3}{ }^{-}$was lower than that reported in previous studies because the proportion of fine particles of $\mathrm{NO}_{3}{ }^{-}$was relatively large (on average, approximately $60 \%$ ).

The atmospheric aerosol concentrations and dry deposition fluxes of each nitrogen compound in this study and other regions (coastal waters) previously reported are shown in Table 2. In the East China Sea, the estimation of the $\mathrm{NO}_{3}^{-}$dry deposition flux was $720 \mu \mathrm{g} \mathrm{N} \mathrm{m}^{-2}$ day $^{-1}$ for $0.48 \mu \mathrm{g} \mathrm{N} \mathrm{m}^{-3}$ of atmospheric concentration(Nakamura et al., 2005). Although the $\mathrm{NO}_{3}{ }^{-}$atmospheric concentration was $0.85 \mu \mathrm{g} \mathrm{N} \mathrm{m}{ }^{-3}$ in this study, which is higher than that in the East China Sea, the dry deposition flux was $660 \mu \mathrm{g} \mathrm{N} \mathrm{m}{ }^{-2}$ day $^{-1}$, which was equivalent to the East China Sea. These differences reported can be attributed to the high proportion of $\mathrm{NO}_{3}{ }^{-}$existing as fine particles, and the low deposition velocity in the coastal area of the Seto Inland Sea. The atmospheric concentration and dry deposition flux of $\mathrm{NH}_{4}{ }^{+}$in the East China Sea were $2.3 \mu \mathrm{g} \mathrm{N} \mathrm{m}^{-3}$ and $450 \mu \mathrm{g} \mathrm{N} \mathrm{m}^{-2}$ day $^{-1}$, respectively (Nakamura et al., 2005), while in the coastal region of the Seto Inland Sea, these concentrations were $1.6 \mu \mathrm{g} \mathrm{N} \mathrm{m}^{-3}$ and $280 \mu \mathrm{g} \mathrm{N} \mathrm{m}^{-2}$ day $^{-1}$, respectively. This is because the size distributions are comparable, which means that the deposition flux is roughly proportional to the concentration in the atmosphere. The $\mathrm{NO}_{3}{ }^{-}$deposition flux from the atmosphere is the largest among the nitrogen compounds, accounting for $64 \%$ of the total, because the size distribution is mostly biased toward the coarse sizes.

In this study, the dry deposition of gaseous substances $\left(\mathrm{HNO}_{3}\right.$ and $\left.\mathrm{NH}_{3}\right)$ and wet deposition $\left(\mathrm{NO}_{3}{ }^{-}\right.$and $\left.\mathrm{NH}_{4}{ }^{+}\right)$were not measured; however, the deposition flux of inorganic nitrogen (dry and wet) was estimated with reference to the observation results from the Oki Islands, located in the Sea of Japan (Ban et al., 2016). In the Oki Islands, of the total deposition flux of approximately $3,500 \mu \mathrm{g} \mathrm{N} \mathrm{m}^{-2}$ day $^{-1}$, dry deposition flux of aerosols and gaseous substances was approximately 990 and $710 \mu \mathrm{g} \mathrm{N} \mathrm{m}^{-2}$ day $^{-1}$, while the wet deposition flux was approximately $1,800 \mu \mathrm{g} \mathrm{N} \mathrm{m}^{-2}$ day $^{-1}$, respectively, indicating that the dry deposition flux from particulate matter accounts for approximately $28 \%$ of the total. The annual rainfall in the Oki Islands was $1,339 \mathrm{~mm}$ (Ban et al., 2016), while for the same period at a location approximately $15 \mathrm{~km}$ from the observation station in this study, it was $1,108 \mathrm{~mm}$, as calculated from rainfall data by 

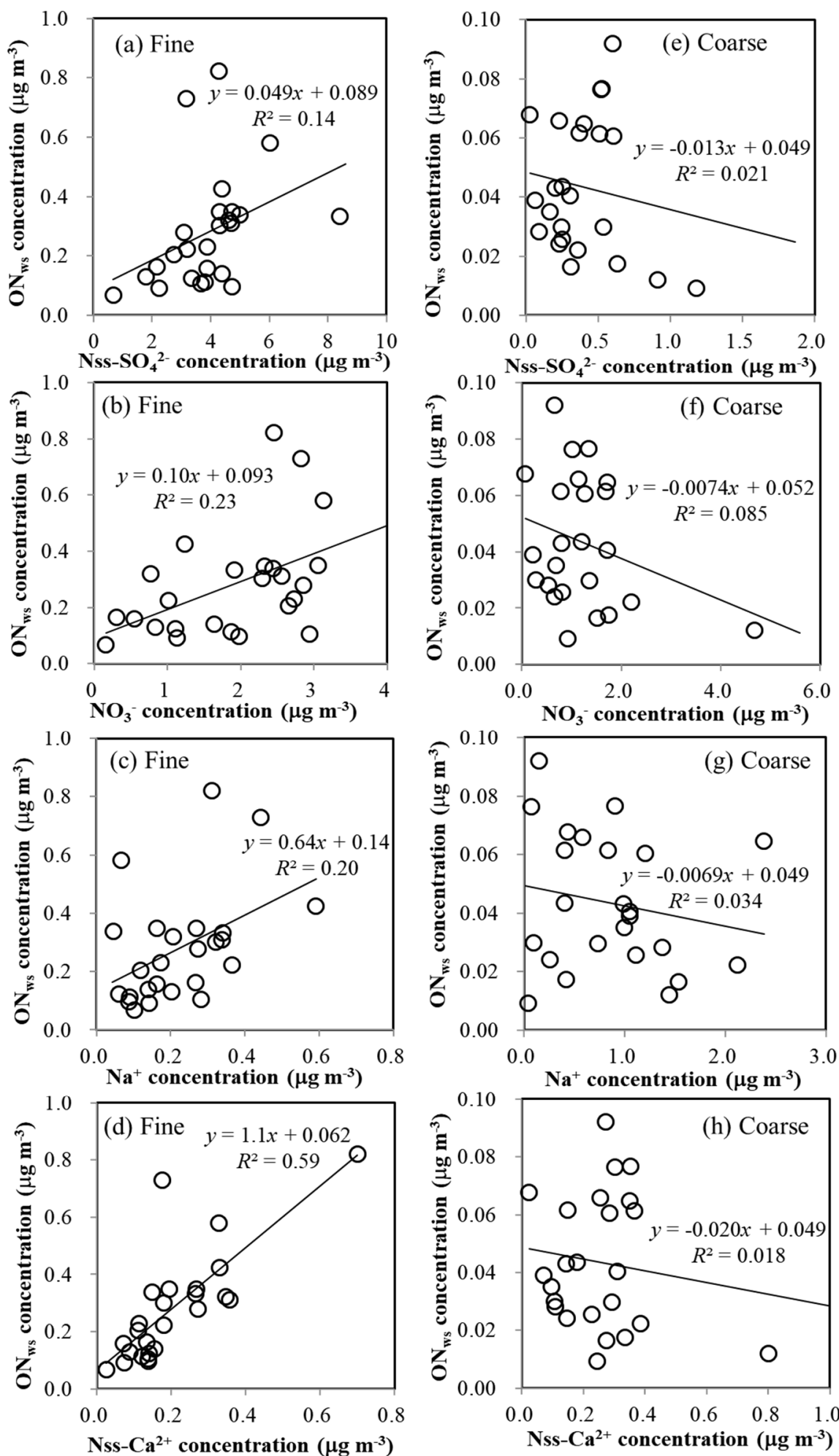

Fig. 9. Relationships between nss- $\mathrm{SO}_{4}{ }^{2-}, \mathrm{NO}_{3}{ }^{-}, \mathrm{Na}^{+}$, and nss-- $\mathrm{Ca}^{2+}$ and $\mathrm{ON}_{\mathrm{ws}}$, in fine (a)-(d) and coarse (e)-(h) particles.

the Japan Meteorological Agency (http://www.data.jma.go. jp/gmd/risk/obsdl/ index.php; accessed 02 Dec. 2016). The amount of rainfall at the observation point in this study was slightly less, but the wet deposition flux was similar at both locations; therefore, the total deposition flux would be expected to be approximately four times the dry deposition flux. Therefore, it is also necessary to consider both gaseous substances and wet deposition to estimate the total deposition flux of nitrogen compounds.

The dry deposition flux of $\mathrm{ON}_{\mathrm{ws}}$ was small, accounting for approximately $8.1 \%$ of nitrogen compounds, but the behavior of $\mathrm{ON}_{\mathrm{ws}}$ was different from that of $\mathrm{NH}_{4}{ }^{+}$and $\mathrm{NO}_{3}{ }^{-}$ 
Table 2. Comparison of average ambient concentrations of nitrogen compounds and deposition flux in different coastal regions.

\begin{tabular}{|c|c|c|c|c|c|c|c|}
\hline \multirow{2}{*}{ Location } & \multicolumn{3}{|c|}{ Seto Inland Sea } & \multicolumn{2}{|c|}{ Pacific Ocean } & \multicolumn{2}{|c|}{ East China Sea } \\
\hline & $\mathrm{NO}_{3}^{-}$ & $\mathrm{NH}_{4}^{+}$ & $\mathrm{ON}_{\mathrm{ws}}$ & $\mathrm{NO}_{3}^{-}$ & $\mathrm{NH}_{4}^{+}$ & $\mathrm{NO}_{3}^{-}$ & $\mathrm{NH}_{4}^{+}$ \\
\hline Ambient concentration $\left(\mu \mathrm{g} \mathrm{N} \mathrm{m}^{-3}\right)$ & 0.85 & 1.6 & 0.28 & 0.17 & 0.30 & 0.48 & 2.3 \\
\hline Deposition flux ( $\mu \mathrm{g} \mathrm{N} \mathrm{m}^{-2}$ day $\left.^{-1}\right)$ & 660 & 280 & 83 & 250 & 66 & 720 & 450 \\
\hline Deposition flux Ratio (\%) & 65 & 27 & 8.1 & 79 & 21 & 62 & 38 \\
\hline Reference & \multicolumn{3}{|c|}{ This study } & \multicolumn{4}{|c|}{ Nakamura et al., 2006} \\
\hline
\end{tabular}

in some samples; in addition, the atmospheric concentrations of $\mathrm{ON}_{\mathrm{ws}}$ may account for up to $40 \%$ of $\mathrm{TN}_{\mathrm{ws}}$. Therefore, $\mathrm{ON}_{\mathrm{ws}}$ should be considered in evaluating the effects of nitrogen compounds on marine ecosystems.

\section{CONCLUSIONS}

The chemical compositions of atmospheric aerosols were measured in the coastal aera of Seto Inland Sea between February 15 and March 20, 2015. In this study, we focused on the nitrogen compounds by the chemical forms (organic and inorganic) in aerosols that are utilized as nutrients in the ecosystems.

During all observation periods, the mean concentrations of $\mathrm{NH}_{4}^{+}, \mathrm{NO}_{3}^{-}$and $\mathrm{ON}_{\mathrm{ws}}$ in the total (fine and coarse) particles were $1.6,0.85,0.28 \mu \mathrm{g} \mathrm{N} \mathrm{m}^{-3}$, respectively. The contribution of $\mathrm{ON}_{\mathrm{ws}}$ to the total nitrogen was approximately $10 \%$, however, these fractions are comparable to the contribution of fine $\mathrm{NO}_{3}{ }^{-}$and coarse $\mathrm{NH}_{4}{ }^{+}$.

A correlation analysis between $\mathrm{ON}_{\mathrm{ws}}$ and $\mathrm{nss}-\mathrm{SO}_{4}{ }^{2-}$, $\mathrm{NO}_{3}{ }^{-}, \mathrm{Na}^{+}$and soil nss-Ca ${ }^{2+}$ was conducted for each particle size to determine the sources of $\mathrm{ON}_{\mathrm{ws}}$ in the aerosols. Significant correlations were seen with the fine particles, though not with the coarse particles. Based on the correlations between $\mathrm{ON}_{\mathrm{ws}}$ with nss- $\mathrm{SO}_{4}{ }^{2-}$ and $\mathrm{NO}_{3}{ }^{-}$, combustion could be considered as a source of $\mathrm{ON}_{\mathrm{ws}}$. But it could not be identified whether $\mathrm{ON}_{\mathrm{ws}}$ was from long distance transport or locally derived.

The dry deposition flux of particulate nitrogen compounds was estimated. The $\mathrm{NO}_{3}{ }^{-}$deposition flux from the atmosphere is the largest among the nitrogen compounds, accounting for $64 \%$ of the total, because the size distribution is mostly biased toward the coarse sizes. The dry deposition flux of $\mathrm{ON}_{\mathrm{ws}}$ was small, accounting for approximately $8.1 \%$ of nitrogen compounds, but the behavior of $\mathrm{ON}_{\mathrm{ws}}$ was different from that of $\mathrm{NH}_{4}{ }^{+}$and $\mathrm{NO}_{3}{ }^{-}$in some samples; in addition, the atmospheric concentrations of $\mathrm{ON}_{\mathrm{ws}}$ may account for up to $40 \%$ of $\mathrm{TN}_{\mathrm{ws}}$. Therefore, $\mathrm{ON}_{\mathrm{ws}}$ should be considered in evaluating the effects of nitrogen compounds on marine ecosystems.

Further research is necessary, including observations of other seasons and the measurements of $\mathrm{ON}_{\mathrm{ws}}$ in wet deposits and gaseous matter to understand the sources and formation of $\mathrm{ON}_{\mathrm{ws}}$, and the nitrogen cycle in this study area.

\section{ACKNOWLEDGMENTS}

This research was supported by the Cooperative Program (No. 148, 2016; No. 146, 2015) of Atmosphere and Ocean
Research Institute, The University of Tokyo.

\section{REFERENCES}

Ban, S., Matsuda, K., Sato, K. and Ohizumi, T. (2016). Long-term assessment of nitrogen deposition at remote EANET sites in Japan. Atmos. Environ. 146: 70-78.

Chen, H.Y., Hung, C.C., Fang, T.H. and Gong, G.C. (2008). Dry deposition and particle-size distribution of phosphorus in the marine atmosphere over the northeastern coast of Taiwan. Cont. Shelf Res. 28: 756-766.

Cornell, S.E., Jickells, T.D., Cape, J.N., Rowland A.P. and Duce, R.A. (2003). Organic nitrogen deposition on land and coastal environments: A review of methods and data. Atmos. Environ. 37: 2173-2191.

Cornell., S., Rendell, A. and Jickells, T. (1995). Atmospheric inputs of dissolved organic nitrogen to the oceans. Nature 376: 243-246.

Draxler, R.R. and Rolph, G.D. (2016). HYSPLIT (HYbrid Single-Particle Lagrangian Integrated Trajectory) Model access via NOAA ARL READY Website, NOAA Air Resources Laboratory, Silver Spring, MD, http://ready.arl. noaa.gov/HYSPLIT.php, Last Access: 26 September 2016.

Duce, R., Liss, P., Merrill, J., Atlas, E., Buat-Menard, P., Hicks, B., Miller, J., Prospero, J., Arimoto, R. and Church, T. (1991). The atmospheric input of trace species to the world ocean. Global Biogeochem. Cycles 5: 193-259.

Hansell, D.A. (1993). Results and observations from the measurement of DOC and DON in seawater using a hightemperature catalytic oxidation technique. Mar. Chem. 41: 195-202.

Hori, Y., Mochizuki, S. and Shimamoto, N. (2008). Relationship between the discoloration of cultivated Porphyra thalli and long-term changes of the environmental factors in the northern part of HarimaNada, eastern Seto Inland Sea, Japan. Bull. Jpn. Soc. Fish. Oceanogr. 72: 107-112 (in Japanese).

Ishii, D. and Yanagi, T. (2006). Pacific Ocean Originated Phosphorus and Nitrogen in the Seto Inland Sea, Japan. Bull. Coastal Oceanogr. 43: 119-127 (in Japanese).

Itahashi, S., Hayami, H., Uno, I., Pan, X. and Uematsu, M. (2016). Importance of coarse-mode nitrate produced via sea salt as atmospheric input to East Asian oceans. Geophy. Res. Lett. 43: 5483-5491.

Jickells, T., Baker, A.R., Cape, J.N., Cornell, S.E. and Nemitz, E. (2013). The cycling of organic nitrogen through the atmosphere. Philos. Trans. R. Soc. London, Ser. B 368: 20130115, doi: 10.1098/rstb.2013.0115. 
Kang, J., Cho, B.C. and Lee, C.B. (2010). Atmospheric transport of water-soluble ions $\left(\mathrm{NO}_{3}{ }^{-}, \mathrm{NH}_{4}{ }^{+}\right.$and nss$\mathrm{SO}_{4}{ }^{2-}$ ) to the southern East Sea (Sea of Japan). Sci. Total Environ. 408: 2369-2377.

Luo, L., Yao, X.H., Gao, H.W., Hsu, S.C., Li, J.W. and Kao, S.J. (2016). Nitrogen speciation in various types of aerosols in spring over the northwestern Pacific Ocean. Atmos. Chem. Phys. 16: 325-341.

Mace, K.A., Kubilay, N. and Duce, R.A. (2003). Organic nitrogen in rain and aerosol in the eastern Mediterranean atmosphere: An association with atmospheric dust. $J$. Geophys. Res. 108: 4320, doi: 10.1029/2002JD002997.

Matsumoto, K., Yamamoto, Y., Kobayashi, H., Kaneyasu, N. and Nakano, T. (2014). Water-soluble organic nitrogen in the ambient aerosols and its contribution to the dry deposition of fixed nitrogen species in Japan. Atmos. Environ. 95: 334-343.

Matsumoto, K. and Yamato, K. (2016). Uncertainties in the measurements of water-soluble organic nitrogen in the aerosol. Atmos. Environ. 144: 220-225.

Murphy, D.V., MacDonald, A.J., Stockdale, E.A., Goulding, K.W.T., Fortune, S., Gaunt, J.L., Poulton, P.R., Wakefield, J.A., Webster, C.P. and Wilmer, W.S. (2000). Soluble organic nitrogen in agricultural soils. Biol. Fertil. Soils 30: 374-387.

Nakamura, T., Matsumoto, K. and Uematsu, M. (2005). Chemical properties of aerosols and transport from the Asian continent to the East China Sea in autumn. Atmos. Environ. 39: 1749-1758.

Nakamura, T., Ogawa, H., Kumar, D.M. and Uematsu, M. (2006). Contribution of water soluble organic nitrogen to total nitrogen in marine aerosols over the East China Sea and western North Pacific. Atmos. Environ. 40: 72597264.

Nakamura, T., Misaki, Y. and Uematsu, M. (2015). The nitrogen components of atmospheric aerosols in the coastal area of Seto Inland Sea in Spring. Proc. of 2015 Annual Meeting of Japan Society for Atmospheric Environment, p. 487 (in Japanese).

Paumen, M.L., de Voogt, P., van Gestel, C.A.M. and Kraak, M.H.S. (2009). Comparative chronic toxicity of homoand heterocyclic aromatic compounds to benthic and terrestrial terrestrial invertebrates: Generalizations and exceptions. Sci. Total Environ. 407: 4605-4609.

Scudlark, J.R., Russell, K.M., Galloway, J.N., Church, T.M. and Keene, W.C. (1998). Organic nitrogen in precipitation at the mid-Atlantic US coast-methods evaluation and preliminary measurements. Atmos. Environ. 32: 17191728.

Shi, J., Gao, H., Qi, J., Zhang, J. and Yao, X. (2010). Sources, compositions, and distributions of water-soluble organic nitrogen in aerosols over the China Sea. $J$. Geophys. Res. 115: D17303, doi: 10.1029/2009JD013238.

Smidt, S. (1994). Endangering of forest trees by organic air pollutants. J. Plant Dis. Prot. 101: 423-445.

Tada, K., Fujiwara, M. and Honjo, T. (2010). Water Quality and Nori (Porphyra) Culture in the Seto Inland Sea. Bunseki Kagaku 59: 945-955 (in Japanese).

Tanda, M., Akashige, S., Ariyama, H., Yamanoi, H., Kimura, H., Dan, A., Sakamoto, H., Saiki, Y., Ishida, Y., Kotobuki, H. and Yamada, T. (2014). Nutrient environment and fisheries in the Seto Inland Sea. J. Fish. Technol. 7: 3746 (in Japanese).

Uematsu, M., Sugita, T., Anikiev, V.V. and Medvedev, A.N. (1992). Large-scale transport of pollution aerosol over the East Coast of Asia. Geophy. Res. Lett. 19: 22192221.

Uematsu, M., Hattori, H., Nakamura, T., Narita, Y., Jung, J., Matsumoto, K. and Kumar, D. (2010). Atmospheric transport and deposition of anthropogenic substances from the Asia continent to the East China Sea. Mar. Chem. 120: 108-115.

Uematsu, M., Toratani, M., Kajino, M., Narita, Y., Senga, Y. and Kimoto, T. (2004). Enhancementof primary productivity in the western North Pacific caused by the eruption of the Miyake-jima Volcano. Geophy. Res. Lett. 31: L06106, doi: 10.1029/2003GL018790.

Zhang, Y., Liu, X.J., Fangmeier, A., Goulding, K.T.W. and Zhang, F.S. (2008). Nitrogen inputs and isotopes in precipitation in the North China Plain. Atmos. Environ. 42: 1436-1448.

Zhou, M.Y., Yang, S.J., Parungo, F.P. and Harris, J.M. (1990). Chemistry of marine aerozols over the western Pacific Ocean. J. Geophys. Res. 95: 1779-1787.

Received for review, January 2, 2020 Revised, January 2, 2020 Accepted, March 5, 2020 